\title{
A Great Divide: Polish media discourse on migration, 2015-2018
}

Marek Troszyński (iD ${ }^{1 凶} \&$ Magdalena El-Ghamari (iD ${ }^{1}$

The widely described migration crisis in Europe took place in 2015-2018. Like any major event, it was covered by the media in a variety of ways. While one could find analyses of the related media content for many European countries, a comprehensive study for Poland has not been previously conducted. This paper describes the Polish media's divided positions on migration from 2015 to 2018. The media content analysis was based on the monitoring of the press, television, and the Internet. The following research techniques were used: (1) a summary of the number of messages over particular months to show the intensity of the phenomenon, (2) quantitative analysis employing corpus linguistics (CL), (3) qualitative analysis using critical discourse analysis (CDA). The analyses revealed a sharp divide between conservative and liberal discourses. These differences-tone, sentiment, and subject matter-were apparent in how the migration crisis was described. Conservative media only showed negative aspects of migration, and if there were no such issues in Poland, protests against migrants in Europe became their chosen topic. Liberal media much more often referred to the specificity of migration to Poland (economic migration from Ukraine) and showed the need for solidarity with migrants. However, the dominant difference was the political sympathies of individual media. We have shown divisions in media coverage based on this very factor. Tabloid coverage was not associated with any political party; it criticized the actions of the government and the opposition. However, the most critical perspective from which we want to describe the collected material is the securitization of migration. The subject of security is present in each analysed discourse, regardless of political divisions. Our research shows though that the intensity of threats is more significant in the right-wing press.

\footnotetext{
${ }^{1}$ Collegium Civitas Warsaw, Warsaw, Poland. ${ }_{\text {email: mtroszynski@civitas.edu.pl }}$
} 


\section{Introduction}

igration in Poland differs from other EU countries. Emigration from Poland still exceeds immigration, although the balance has shifted in favour of the latter since 2015. Immigration to Poland is still principally economic, with arrivals seeking stable employment and improved earnings. According to the Ministry of Family, Labour and Social Policy, nearly 1.5 million foreigners work in Poland, an underestimate due to the unknown quantity of illegal workers.

The highest number of applications for permanent residence over 2017-2018 was by citizens from Ukraine, followed by Belarus, Russia, Vietnam, and Armenia. Ukrainians are the most influential national group among foreigners working in Poland. Just over half a million Ukrainians were registered with the Social Insurance Institution (ZUS) by the end of 2020, meaning three out of four foreigners working in Poland are from Ukraine (ZUS 2020).

We analysed media discourse over 2015-2018 because those precise years witnessed increased migratory waves from Africa and the Middle East into the territory of the European Union. Specifically, the last quarter of 2015 saw 1 million refugees reach Europe (FRAN Quarterly, 2015 Q4-978,338), an increase on the previous year of $1126 \%$ (2015). Migration dramatically slowed by mid-2018 (2018 Q2-45,511), with a decrease on the previous year of $45 \%$ (FRAN Quarterly 2018).

The immigration crisis, arising from mass migration to Europe, became a significant issue for the 2015 (parliamentary) and 2018 (local) election campaigns in Poland. It is vital to highlight the importance of policy decisions in shaping the discourse on migrants in Poland. As Michał Krzyżanowski noted, "the second half of 2015 brought a significant change to the Polish political discourse. This change was characterized by a rapid move from a near lack of any immigration-related debates, to a strong and forceful anti-immigrant rhetoric of discrimination or even outright hatred towards migrants and, in particular, asylum seekers arriving in Europe (Krzyżanowski, 2018, p. 76).

In a hybrid media system, traditional and online media are intertwined (Chadwick, 2013). Despite the rapid development of internet communication and social media, through articles and analyses circulating in the public space, the press still plays an important role in shaping opinions, setting the agenda, presenting the positions of political actors, and shaping the knowledge of opinion leaders (including journalists) (Reinemann, 2004, p. 864). Online newspapers are of particular importance, allowing the press to participate in 'many to many' communication (Li, 1998).

Despite the great diversity of global media, there is an increasing trend for political polarization into two distinct opposing camps (Yang et al., 2016); this may also be seen in nonpolitical news (Iyengar and Hahn, 2009). A marked political division within the discourse is also detectable in Poland. The press market is divided into nationalist and conservative newspapers (e.g. Nasz Dziennik, Gazeta Polska Codziennie) on one side, and modernist and pro-European titles (Gazeta Wyborcza, Rzeczpospolita) on the other (Troszyński, 2021).

Gazeta Wyborcza and Gazeta Polska Codziennie were the papers analysed for this study. Interestingly, these two titles, representing two contrasting worldviews, also appear in other studies of migration discourse (see Wenzel and Żerkowska-Balas, 2019). This analysis will treat tabloid discourse separately from the opinion-forming press (Bączkowska, 2019)

This study aims to describe the dynamics shaping the discourse on migrants, and above all, to map the main topics. This will make it possible to establish the axis of the discussion and describe the factors that make up the securitization of discourse. Although the article is centred on an analysis of Polish media discourse, it is worth introducing several important categories used to describe the phenomenon of migration.

The terms "migrant" and "refugee" employed herein should be defined. Migrant is an umbrella term, not specified by international law, reflecting the lay understanding of a person who leaves their place of usual residence, whether within a country or across an international border, temporarily or permanently, and for a variety of reasons. The term includes a number of well-defined legal categories of people, such as migrant workers; persons whose particular types of movements are legally defined, such as smuggled migrants; as well as those whose status or means of movement are not specified by international law, such as international students (Carling, 2017).

According to the 1951 Refugee Convention, a refugee is a person who: "owing to well-founded fear of being persecuted for reasons of race, religion, nationality, membership of a particular social group or political opinion, is outside the country of his nationality and is unable or, owing to such fear, is unwilling to avail himself of the protection of that country; or who, not having a nationality and being outside the country of his former habitual residence as a result of such events, is unable or, owing to such fear, is unwilling to return to it" (UNHCR, 2011). Obviously, the accepted theoretical distinctions are not fully perceived by the recipients of public discourse.

The main subject of analysis in this study will be the securitization of migration. Considering the article's conceptual framework, we suggest that the topic of securitization requires development and placement in the source literature, and an indication of the relationship between securitization and migration issues (Bigo, 2001, 2002; Bourbeau, 2011; Bartoszewicz, 2016; Huysmans, 2006). The Copenhagen School first proposed this approach to underpin the 'widening' remit of security studies. The developers of this concept, Buzan, Wæver and Wilde, defined securitization as 'a move that takes politics beyond the established rules of the game and frames the issue either as a special kind of politics or as above politics' (Buzan et al., 1998, p. 23). The Copenhagen School places a premium on 'speech acts', stressing that the very utterance of 'security' is more than just saying or describing something, but also performing an action (Léonard and Kaunert, 2011; Stritzel, 2007; Balzacq, 2011; Roe, 2008; Waever, 1995). Since its emergence as an alternative approach to traditional security studies, securitization has, become an attractive and challenging concept for researchers and international relations. It has helped to determine, present and explain more systematically how mundane occurrences are transformed into security issues (Bigo, 2000; Bourbeau, 2011; Côté, 2016; Huysmans, 2006; Léonard and Kaunert, 2011; Stritzel, 2014). The question of security is highly mutable and complex. On the one hand, it refers to an existential need of individuals, states and social systems, and on the other, it is an element of the raison d'état of the state and an outline of international relations (Léonard and Kaunert, 2011). At the same time, a dynamic state and social process take place in the international environment. In the most general sense, security means meeting the needs recognized as existential by an individual, society, state or global system within the international environment. These needs primarily include existence, independence, identity and development. The negative aspect of security lies in a lack of threats, while the positive element involves activities aimed at ensuring the conditions of survival and growth.

The field of security issues has expanded to include migration flows and trans-frontier flows. Europeanization has had the effect of allowing a logic of confidentiality to come to the forefront. It meant that administrations and experts from each country had to 
confront each other, but it also allowed them to avoid dialogues with other sectors in their own society. Politicians' fears concerning the political violence of Islamic radicalism, discourses on urban insecurity, and the transformation of migration flows play a decisive role in the progressive politicization of crime, insecurity and immigration. Internal security emerged at a time when economic and social questions began to be approached from a security and cultural angle and when this latter perspective became important in determining institutional replies to these questions (Bigo, 2000). The theory of securitization is that the articulation of security produces a specific dire state of affairs. Within this theory, power is derived from the use of 'appropriate' words in compliance with established rules governing speech acts. Many security utterances contradict the 'rule of sincerity', and the intrinsic power attributed to 'security overlooks the objective context in which security agents are situated. Three basic assumptions are that effective securitization is audience-centred, and effective securitization is power-laden and context-dependent (Balzacq, 2005). Securitization is also a highly intersubjective process involving active audiences. Securitization theory characterizes audiences as agents without agency, thereby marginalizing the theory's intersubjective nature (Côté, 2016). Other scholars have also contributed to developing and refining the securitization approach. For instance, Eriksson (1999) argued that securitization does not provide a real explanation as to why only some specific instances of securitization influence the security agenda but not all. Balzac offered a more profound commentary on the concept of securitization, considering that it should be split into philosophical/traditional and social/pragmatic variants. While the former reflects the 'speech act'-understanding of securitization that reduces security to a conventional procedure, such as marriage or betting, the latter variant is a process-oriented securitization; that is, a strategic process that occurs within and as part of a configuration of circumstances. This includes the context, the psycho-cultural disposition of the audience, and the power that both speaker and listener bring to the interaction (Balzacq, 2011). The core constituents of the securitization process-speech acts, securitizing actors and the audience-are equally important for both philosophical and sociological approaches to securitization. Still, their way of operation is fundamentally distinct in each variant. For instance, if the audience is a formal category for the philosophical view, then the sociological theory (Paris School) emphasized the mutual constitution of securitizing actors and their audience (Bigo, 2000, 2001, 2002; Balzacq, 2011). The Copenhagen School argues: 'It is the actor [...] who decides whether something is to be handled as an existential threat'; 'Successful securitization is not decided by the securities but by the audience of the security speech act', and these core arguments are considered as contradictory by other scholars and researchers. For an overview, see Buzan et al. (1998, p. 31). Consequently, the interactions between a securitizing actor and the audience have to be reconceptualized (Roe, 2008, p. 618). Stritzel also sought to better conceptualize the relationship between the core constituents of securitization-securitizing actors, speech acts and audience. The focus is then on the relationships between core constituents in each phase (Stritzel, 2007, 2014).

This study assumes that all of the above aspects are significant, and impact the perception of migration. The securitization of migration according to the analytical framework permits the inclusion of time in the analytical framework by opting for a "moving pictures" approach to the phenomenon of securitized migration instead of taking merely a "snapshot" view of the phenomenon (Paul Pierson, 2004). Worldwide political rhetoric, however, increasingly links migration to the destabilization of public order in destination states (Doty, 1996; Ugur, 1995).
Despite decisions to halt labour immigration, the immigrant population has grown due to permission to immigrate based on family reunions. As a result, public awareness of the immigrant population increased. The temporary guest workers more and more became permanent settlers who could not easily claim that they would return home. In a sense, they became permanent guests (Sayad, 1991, 1994). Consequently, migration securitization studies should be able to explain the differences in the levels of migration securitization. As the above analysis of securitization theory demonstrates, security should be treated as a multidimensional or binary concept. This makes it impossible to explain the variability of the levels of securitized migration. The only variation that the theory recognizes is the spectrum from politicization, securitization, and desecuritization. Once an issue has reached the securitization phase, the securitization approach does not distinguish whether it is strongly or weakly securitized. This is problematic because, if there is variability, there is no theoretical space in the current organization and application to provide appropriate guidance for suggesting hypotheses explaining variation within or between cases (Bourbeau, 2011). Migration has been controlled through national policies and bilateral and/or multilateral agreements for a long time. Moreover, the notion that specific individuals could pose security threats has been a reality for many years. The factors that have recently begun to cause concern, however, are (1) the notion of migration in a collective sense posing an existential threat to the security of the state and/or the society; (2) the prominence given to immigration as a security threat; and (3) its attendant effects in political practice, which have undergone significant and even startling changes (Bigo, 2001, 2002, Bourbeau, 2011).

\section{Methods}

The study aims to present the media discourse in Poland from as many perspectives as possible, using three research tools:

- media content analysis-a quantitative perspective (corpus linguistics (CL)),

- media content analysis-a qualitative perspective (critical discourse analysis (CDA)).

These two perspectives are often combined in discourse studies (Baker et al., 2008; Gabrielatos and Baker, 2008; Nartey and Mwinlaaru, 2019).

The first step in media content research was collecting the appropriate text corpora. The following criteria were used to collect texts describing migration and migrants:

- Keywords: migracje OR *migrant OR *migrantka (emigrant, immigrant, migrant, emigrantka, imigrantka, migrantka) OR uchodźcy OR nachodźcy [migrations OR migrant (emigrant, immigrant, migrant) OR refugee]

- Monitoring range:

- TV stations (TVP1, Polsat, TVN, TVP Info, TVN 24),

- Press: dailies: Fakt, Super Express, Gazeta Wyborcza, Dziennik Gazeta Prawna, Rzeczpospolita, Gazeta Polska Codziennie; weeklies: Gość Niedzielny, Polityka, Newsweek Polska, Sieci, Tygodni Do Rzeczy

- Internet: wp.pl, onet.pl, interia.pl, gazeta.pl, polki.pl

- Monitoring time: 1. January 2015-December 31, 2018.

The finished corpus consisted of 18,563 texts grouped by press title and date of publication.

The most common method of analysing media texts, in particular the press, is CDA (or more broadly critical discourse studies-CDS). "Consequently, CDS has been associated with scholars among whose central inspirations are critical theory, 
interdisciplinarity, and linguistics" (Krzyżanowski and Forchtner, 2016 , p. 254). In the world of today's fragmented media, CDA can be employed to illustrate the diversity of broadcasters, communication channels, and modes of delivery- "the increasing discontinuity and fragmentation of public and other modes of discourse" (Krzyżanowski and Forchtner, 2016, p. 256).

At the same time, when examining extensive collections of texts, e.g. press articles collected over several years, it is worth turning to quantitative methods of content analysis. In this field, the methods developed by CL have primacy (Sinclair, 1991; Friginal and Hardy, 2021). The popularity of this approach has increased in the 21st century (Fairclough, 2000; Piper, 2000; Baker, 2006). The strengths of CL allow it to be encoded in media content analysis-"Corpus-based analysis allows researchers to identify more or less objectively widespread patterns of naturally occurring language and rare instances, both of which may be overlooked in a small-scale analysis" (Baker, 2004, p. 346). Media content analysis is directed at finding meanings assigned to individual texts. Simple tools, e.g. analysis of frequencies, do not serve to determine the subject of messages, which is the purpose of this study. Therefore, it is also worth using other indicators, i.e. collocations. As Baker notes, "Because the collocates of a node contribute to its meaning (...), they can provide 'a semantic analysis of a word' (Sinclair, 1991) but can also 'convey messages implicitly' (Hunston, 2002)" (2008, p. 278).

Usually, each collocation analysis must be supported by a concordance analysis performed by the researcher. Qualitative interpretation allows unambiguous reference to the meanings contained in an analysed text. In addition, the more sophisticated CL tool, supported by natural language processing (NLP), allows both the quantitative ordering of research material and labelling the meanings of individual or groups of utterances. Such tools include automatic keyword identification or term extraction (https://www.sketchengine.eu/blog/the-best-term-extraction/).

Examples of effective and efficient combinations of CDA with CL can especially be found in research related to migrant content analysis (Baker et al., 2008). When comparing the two methods of text analysis (CL and CDA), it is possible to recognize the advantages and disadvantages of qualitative and quantitative methods in social research. As Baker states: "Although the CL analysis made use of the whole corpus, given time and money constraints, a similar approach was not feasible for the CDA analysis. The CDA analysis thus was carried out on a sample of texts from the corpus, chosen in order to facilitate comparability of the results of the two strands" (Baker et al., 2008, p. 277). The use of CDA, even in a very basic form (limited to the qualitative designation of the topics of individual articles) allows for the elimination of those accusations made by some researchers against CL, namely: "researchers are able to execute searches only for formally defined items (...) that many (though not all) corpus analytic studies do not take into account reception, the dynamic nature of discourse, or its context or textual structure" (Bednarek, 2009 , p. 22). In summary, the section on media content analysis was based on the quantification of material using the CL method and tool, complemented by 'standard' CDA.

\section{Results}

The corpus of media messages with keywords comprised 18,563 articles. Most (over half) came from the press (Table 1).

Diachronic change. The number of articles per month in the corpus (Fig. 1) revealed two significant peaks. The first was in September 2015, when the migrant crisis was emerging. The number of texts related to migrants increased dramatically, with a jump from 177 texts on the large websites to 895 published per

Table 1 Number of texts collected for each media type.

\begin{tabular}{lll} 
Websites & Press & TV \\
\hline 5815 & 10,140 & 2608 \\
\hline
\end{tabular}

month. Similarly, in the press, there was an increase from 170 to 508 texts, and on TV stations, from 41 in August to 353 in September. The values above represent the highest monthly number of texts on migrants observed. The same month saw similar increases in most European countries (Georgiou and Zaborowski, 2016).

A smaller increase was observed in June 2017, mainly in the press (447 articles). A review of the subject matter highlights the dispute between the European Commission and the Polish government over the relocation of refugees. Since this was a dispute based on complex legal procedures, the issue benefited from an explainer in the press to help people understand.

Interestingly, analysis of newspaper articles showed that tabloids published far fewer articles on migrants than the opinion-forming press, and tended to use different terms ('refugees', 'illegal refugees') (Eberl et al., 2018, p. 210). In terms of the number of articles, the liberal Gazeta Wyborcza published the most articles on migrants over the whole research period. A large spike was recorded by the conservative-right newspaper Gazeta Polska Codziennie (from 20 to 82), which contributed to fanning hostility towards migrants. A similar situation occurred at the second significant moment-June/July 2017, although the number of articles in Gazeta Polska Codziennie was smaller than the first peak (Fig. 2).

After juxtaposing the number of texts over time, it was necessary to apply the SketchEngine tool for corpus linguistic analysis. This tool rapidly constructed word corpora from supplied texts by performing lemmatisation, co-occurrence analysis, term extraction, or generating a frequency list using morphological analysis and part-of-speech tagging (https:// www.sketchengine.eu/).

Firstly, all articles were collected as word corpora. For each of the analysed press titles, subcorpora were created, enabling a comparison of the content of the analysed texts.

- Tabloids

- Gazeta Polska Codziennie GPC

- Dziennik Gazeta Prawna DGP

- Gazeta Wyborcza GW

Prior to the analyses, all corpora underwent a lemmatisation process, particularly important for a fusional language like Polish. The corpora were then subjected to an analysis of frequencies. When introducing the subject areas, only terms referring to actual people were examined. The advantage of this method is that there is no automatic language processing, ensuring a completely 'transparent' process.

When describing the discourse, nouns that refer to human beings were examined. In Gazeta Wyborcza, this was 'człowiek [person]' (relative frequency $\mathrm{RF}^{1}=2321$ ), then 'uchodźca [refugee]' $(\mathrm{RF}=1931)$ and 'imigrant [immigrant]' $(\mathrm{RF}=1356)$. The results for Gazeta Polska Codziennie were different, with the most common term being 'imigrant [immigrant]' $(\mathrm{RF}=3325)$ and secondly 'uchodźca [refugee]' $(\mathrm{RF}=2096)$. A different order was seen in the tabloid discourse: 'uchodźca [refugee]' $(\mathrm{RF}=4506)$, 'człowiek [person]' $(\mathrm{RF}=2718)$ and 'imigrant [immigrant]' (2299). Table 2 demonstrates that the category 'refugee' was significantly overrepresented in tabloid articles. The expression 


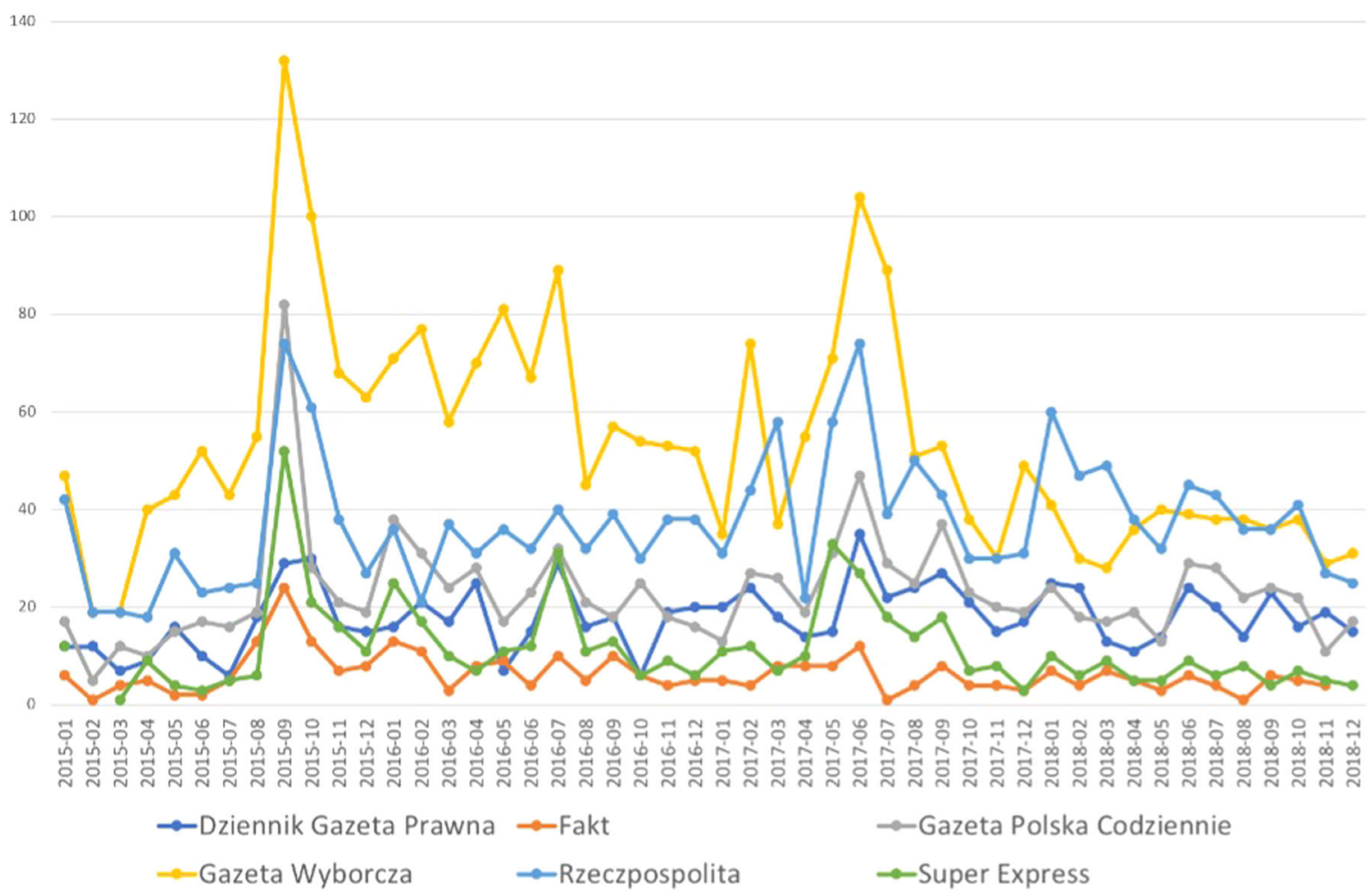

Fig. 1 Number of texts concerning migrants in the Polish media 2015-2018. The graph shows the number of press articles, internet articles and TV broadcasts on migration for the months 2015-2018.

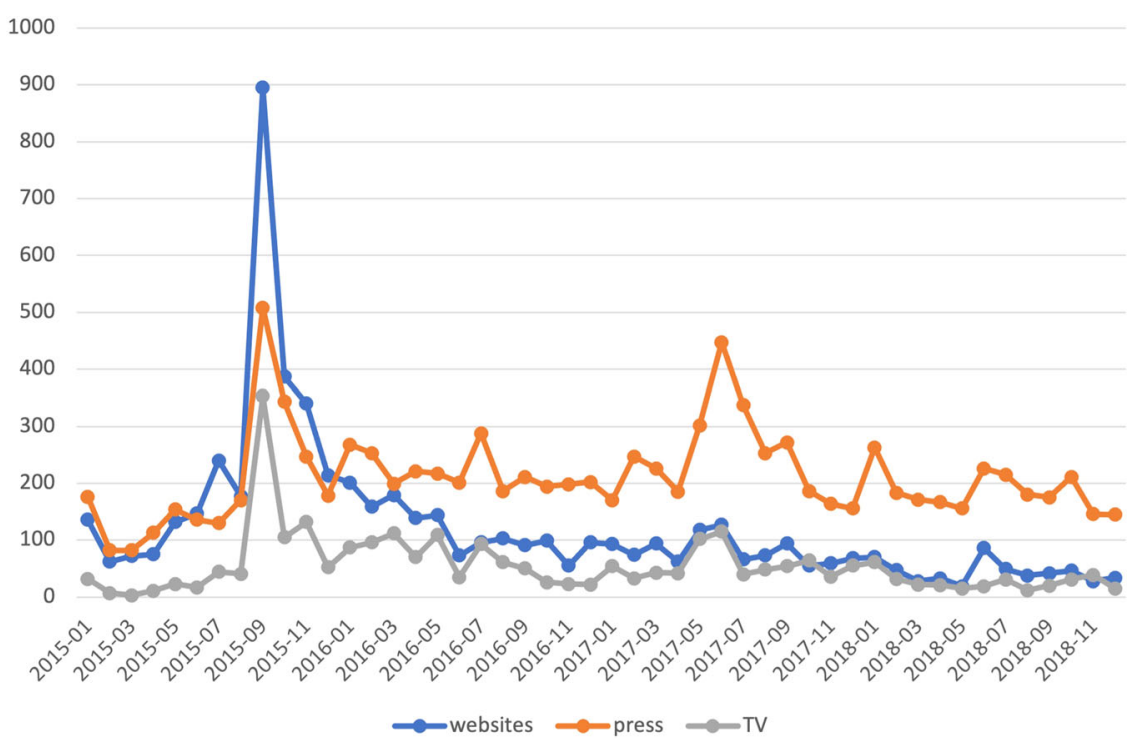

Fig. 2 Articles on migrants in the Polish press, 2015-2018. The chart shows the number of articles in 6 Polish dailies (Dziennik Gazeta Prawna, Fakt, Rzeczpospolita, Gazeta Wyborcza, SuperExpress, Gazeta Polska Codziennie) in individual months 2015-2018.

Table 2 Most frequent nouns in each corpus.

\section{GW}

człowiek [person]

Polska [Poland]

kraj [country]

uchodźca [refugee]

imigrant [immigrant]

Relative frequency

2321

2282

2255

1931

1356
GPC

Polska [Poland] 4310

Imigrant [Immigrant] $\quad 3325$

kraj [country] 3283

państwo [state] 2207

uchodźca [refugee] 2096
Relative frequency

Tabloids

Polska [Poland] 4506

uchodźca [refugee] 4470

człowiek [person] 2718

kraj [country]

imigrant [immigrant]
Relative frequency

4470

2381

2299 


\section{Table 3 Keywords for individual corpora.}

\begin{tabular}{|c|c|c|c|c|c|}
\hline GPC & Score ${ }^{a}$ & GW & Score & Tabloids & Score \\
\hline nielegalny imigrant [illegal immigrant] & 339 & $\begin{array}{l}\text { nielegalny imigrant [illegal } \\
\text { immigrant] }\end{array}$ & 60 & $\begin{array}{l}\text { sprawa uchodźców [the issue of } \\
\text { refugees] }\end{array}$ & 203 \\
\hline $\begin{array}{l}\text { liczba imigrantów [number of } \\
\text { immigrants] }\end{array}$ & 135 & status uchodźcy [refugee status] & 57 & liczba uchodźców [number of refugees] & 173 \\
\hline fala imigrantów [wave of immigrants] & 88 & strefa schengen [Schengen area] & 38 & $\begin{array}{l}\text { tysiąc imigrantów [one thousand } \\
\text { migrants] }\end{array}$ & 116 \\
\hline wschód Ukrainy [east Ukraine] & 87 & fala uchodźców [wave of refugees] & 36 & $\begin{array}{l}\text { sprawa imigrantów [the issue of } \\
\text { immigrants] }\end{array}$ & 100 \\
\hline mld euro & 77 & Le Pen & 35 & nielegalny imigrant [illegal immigrant] & 87 \\
\hline $\begin{array}{l}\text { muzułmański imigrant [Muslim } \\
\text { immigrant] }\end{array}$ & 67 & skrajna prawica [far right] & 30 & szef rady [head of the council] & 83 \\
\hline konwencja rady [Council Convention] & 58 & złoty Świt [Golden Dawn] & 25 & problem uchodźców [refugee problem] & 71 \\
\hline
\end{tabular}

aThe keyness score calculated using the simple maths method for identifying keywords of one corpus vs. another. It includes a variable which allows the user to turn the focus either on higher, or lower frequency words (Kilgarriff, 2009).

appeared more frequently than in other discourses, especially when compared to Gazeta Wyborcza.

The corpora were further processed based on keyword and term extraction (extraction of one- and multi-word units specific to the corpus or defining its content or topic). In this case, the reference corpus was Polish Web 2012 (plTenTen12, RFTagger). The algorithm in the SketchEngine service selected the keywords, and then the researcher analysed the individual concordances and determined the meanings of the listed categories.

As shown in Table 3, tabloids reported on migration differently, in particular, they drew attention to numbers to attract public attention. This is apparent in the example of the aforementioned 'refugee' category, which was linked in tabloid discourse to specific numbers. Paradoxically, tabloids actually discussed refugee issues from various perspectives, unlike the consistent political orientation usually maintained by opinionforming newspapers.

(1) Fakt 2015: To outline how politically complex the problem of deciding on refugees is, remember that the party of Hungarian Prime Minister Viktor Orban (521.), so criticized for xenophobia, belongs to the same political group as Civic Platform!

'Refugee status' was one of the major terms for discourse in GW. Articles assigned to this category discussed the situation of refugees in different regions of the world.

In its texts, $G W$ addressed the 'other side' of the debate on the refugee crisis in Europe, describing how far-right groups ('Le Pen', 'far-right', 'Golden Dawn') contribute to the discourse. Intriguingly, these groups always represented political forces from other countries - there were few texts analysing Polish right-wing parties.

(2) GW1: La Manche: More than 3000 migrants in Calais, France, are trying to break into the UK. The far-right wants to remove them from town; human rights activists appeal for help, and the mayor urges London to open borders. In contrast, the category 'east Ukraine' ranked high in the articles of Gazeta Polska Codziennie, with reports of armed struggle and the evacuation of Poles living in this territory.

(3) D2: POLES IN THE EAST: On the road to their ancestral homeland. Mariupol - Timeline of evacuation. Our compatriots from the east of Ukraine have reached Poland. Their accent is a little strange, as are their clothes, and fear can still be seen in their eyes.
The term 'refugees' appeared less frequently in GPC texts. Instead, the authors used the noun 'migrants'. The second common term was 'Muslim immigrant', usually presented in a negative context.

(4) D0: You must understand that the incident from last month is still fresh in the memory, when Muslim immigrants sailing from Libya to Italy threw twelve of their travel companions overboard, simply because they were Christians praying to Jesus.

Finally, the corpora were analysed for collocations. The analysis was based on semantic preferences, and concordance analysis was applied to the selected utterances. Collocations for the noun 'immigrant' were analysed for the three discourses in question. The following three types of collocation provided the most knowledge about the meanings present in the texts (Tables 4 and 5):

- a word accompanying/modifying a noun ('a_modifier'),

- a verb for the noun as a subject'-'migranci robią' ['migrants do'] ('post_verb')

- a verb for noun as complement-'co robić z migrantami' ['what to do with migrants'] ('prec_vert')

Within each analysed discourse the most popular collocation was 'illegal immigrant'. This significant fact reveals how public debate is shaped, as well as the importance of the legal aspect of migration. $G W$ usually invoked the term 'illegal immigrants' in reference to coverage of political events in other countries.

(5) GW2: (...)take over the electorate of the far-right Jobbik. In the polls, this party, which has scared Hungarians for years with illegal immigrants, increasingly threatens the ruling Fidesz.

GPC also cited news from abroad, although the negative context was prominent.

(6) GPC: Great Britain plans to tighten the rules on controls on arrivals from the continent in order to avoid illegal immigrants. France, on the other hand, fearful of further terrorist attacks, wants more vigilant passenger security checks.

The collocation 'Muslim migrants'-significant for the analysis-appeared in GPC and tabloids. The majority of appearances had a negative context:

(7) GPC: Why do our European leaders decide to accept hundreds of thousands, and perhaps millions, of Muslim 
Table 4 Collocation summary 'a_modifier'.

\begin{tabular}{lclll} 
GPC & score & GW & score & Tabloids \\
\hline nielegalny [illegal] & 13.19 & nielegalny [illegal] & 12.5 & nielegalny [illegal] \\
muzułmański [Muslim] & 11.08 & ekonomiczny [economic] & 10.5 & ekonomiczny [economic] \\
ekonomiczny [economic] & 10.22 & uratować [save] & 9.85 & muzułmański [Muslim] \\
pracować [work] & 9.83 & EU & 9.56 & zarobkowy [labour] \\
\hline
\end{tabular}

Table 5 Collocation summary for post_verb.

\begin{tabular}{lllll} 
GPC & GW & & Tabloid \\
\hline przemycać [smuggle] & 10.51 & szturmować [storm] & 9.98 & uciec [escape] \\
podpalić [set fire to] & 10.47 & zapłacić [pay] & 9.74 & próbować [try] \\
zgromadzić [gather] & 10.38 & spędzać [spend] & 9.35 & stać [stand] \\
postanowić [decide] & 10.27 & przybywać [arrive] & 9.26 & kryć [hide] \\
dotrzeć [reach] & 10.24 & pochodzić [come from] & 9.1 & 10.91 \\
marzyć [dream] & 10.19 \\
\hline
\end{tabular}

Table 6 Collocation summary for "prec_verb".

\begin{tabular}{lllcl} 
GPC & GW & & Tabloid \\
\hline przyjmować [accept] & 10.7 & zatrzymywać [keep] & 10.22 & przemycać [smuggle] \\
zapraszać [invite] & 10.54 & przyjmować [accept] & 10.03 & zaatakować [attack] \\
odsyłać [send back] & 10.54 & dotrzeć [reach] & 9.61 & bać [to fear] \\
\hline
\end{tabular}

immigrants, when this must lead to a change in European identity and civilization?

The "post_verb" collocations provided an answer to the question, "What do immigrants featured in the analysed discourses do?" In the GPC texts, immigrants smuggle/set fire to/gather/decide/reach. In $G W$, immigrants storm/pay/ spend/arrive. There is a noticeable difference in connotations between one set of verbs and the other: GPC presented strongly negative connotations, while $G W$ presented partially neutral connotations. In the tabloid discourse, the dominant collocation was 'immigrants fleeing', but this referred both to fleeing war-torn areas and to specific travel situations:

(8) The captain of the boat sent an SOS signal before the tragedy, but when other vessels started to approach, the immigrants raced to one side of the vessel, causing it to capsize.

As seen in Table 6, tabloid discourse was clear and specific: to smuggle/be attacked by/be afraid of/send/get rid of migrants. 'Accepting' migrants was crucial for both opinion-forming newspapers, especially for GPC in the context of preventing their entry.

(9) GPC: An emotive discussion is sweeping through Poland whether to accept immigrants from Muslim countries-as if the answer was not obvious in the light of the failure of experiments in multiculturalism (...).

\section{CDA-discussion of article topics}

The second stage of analysis was a qualitative interpretation incorporating CDA. In order to examine the articles qualitatively, it was necessary to reduce their number and draw a sample of texts. The study was conducted on a sample of 200 texts. Researchers read and analysed the selected articles, seeking to distinguish prominent themes in the discourse. Based on their linguistic competence, researchers analysed the articles and chose the topics listed in Table 7 . Although only basic CDA methods were employed, these nonetheless revealed the political and social context of the described texts (Wodak and van Dijk, 2000; Reisigl and Wodak, 2001; Mautner, 2007).

The months of September 2015 and June 2017 were chosen as separate periods for initial analysis. The study began in September 2015 , recognizing this as the key moment of the whole crisis and the most significant peak of media citations. The main trending topics for this month in the leading opinion-forming Polish newspapers were identified.

Liberal leaning Gazeta Wyborcza $(G W)$ wrote primarily about the Polish government's position on the mandatory relocation of refugees adopted by the European Commission. The newly appointed PiS government reversed the approach of its predecessor, unequivocally opposing the obligation to accept refugee quotas. $G W$ was critical of the Polish Government, most often referring to the need for European solidarity. An important theme in the published articles was the result of numerous public opinion polls, which indicated a very sharp change in the attitude of Poles towards refugees. $G W$ ran editorials describing examples of earlier Polish solidarity towards refugees, including the end of the 1990s and the first decade of the 21st century when Poland accepted several thousand refugees from Chechnya each year (Boćkowski, 2020, p. 339).

Importantly, threads relating to the threat to security do not dominate the discourse of Gazeta Wyborcza. They appear in the last of the indicated topics, i.e. the activity of migrants in the Balkans, but it is rather a necessity forced by the mainstream agenda setting (Gruszczynski and Wagner, 2017). By analysing the collected content, we can clearly see that GW does not want to sensationalize the violence and threats caused by migrants.

$G P C$ took a contrasting position in the public debate, covering anti-refugee demonstrations and the opposition of sections of Polish society to mandatory quotas. The narrative was coloured by accounts of migrant activity in the Balkans and a feverish vision of Europe being flooded by refugees from Africa and the Middle East.

Here, the vast majority of thematic threads either directly refer to security or at least inform about the threat as the background of the migration processes. The activity of migrants in Hungary 


\section{Table 7 The dominant topics of debate around the subject of refugees.}

\section{GW}

September 2015

- relocation of migrants within the EU,

- reaction of European politicians to the compulsory separation of migrants,

- response of Polish government to compulsory relocations

- information on the activities of migrants in southern Europe (Hungary, the Balkans), arrival of refugees to Germany

- attitude of Polish society towards refugees (opinion polls),

- demonstrations for and against refugees in Poland,

- receiving Chechens in the $90 \mathrm{~s}$

June 2017

- immigrants in Poland, attitude of Poles to Ukrainians,

- Poland's "war" with the EU

- Polish fear of immigrants,

- EC disciplinary proceedings regarding relocation of refugees

\section{GPC}

September 2015

- activities of immigrants in Hungary

- the error of accepting Syrian refugees

- social opposition to forced redistribution of refugees

- Warsaw demonstrations against refugee intake

- refugee activity in the Balkans

- migration from Africa to Europe

June 2017

- terrorist attacks in London,

- EU migration crisis, people smugglers

- EC proceedings against Poland

- policy of other EU countries towards migrants

Table 8 Dominant topics of debate on refugees in tabloids.

SE

September 2015

Main EU countries agreed migrant quotas behind Poland's back

- Quantity of refugees acceptable in Poland

- Arab invasion of Europe

- demonstrations against refugees in Poland

- refugees attack the police (Europe)

- Polish fears of strangers

- Germans received refugees, now Germans fear them

June 2017

- surveys on attitudes to refugees in Poland

- riots by refugees
Fakt

September 2015

- wall on the Hungarian border

- compulsory long-term migrant quotas

- scale of migration from Syria

- "large quarrel in the EU about refugees"

- scholarships for refugees in Poland

- how many refugees must Poland accept June 2017

- EC proceedings against Poland

- EU afraid of terrorists

- London terror attack and the Balkans is the main news that is supposed to bring a sense of danger to readers. When GPC reports on the situation in Poland, although it cannot write about any immediate threat caused by migrants, it describes demonstrations against the admission of migrants.

In 2017, the most important change concerned the shift in attitudes towards migrants (cf. CBOS, 2016). Poles changed their attitude towards migrants to hostile and unwelcome (figures), which is closely related to the media discourse. GW also begins to write about the fear of migrants among Poles.

GW attributed the change in Polish attitudes to the antiimmigration policy of PiS. In addition, migrants from Ukraine, the largest group of foreigners residing in Poland, became an important topic. The second major factor was the protracted dispute between Poland and the EC over mandatory relocation quotas.

GPC criticized the actions of the EC, portraying Poland as a victim of the 'crazy' bureaucrats in Brussels. In the case of GPC, there already is a full overview of all possible threats related to migration. The attacks in London, the crisis caused by the migrations of 2015 in Western European countries, smuggling people across borders. The narrative tone was heightened by accounts of alleged crimes and attacks committed by migrants in EU countries.

The themes dominating the tabloid narrative were notably different from those of the opinion-forming press. Table 8 represents data for the daily titles Fakt and Super Express (SE). In September 2015, SE was dominated by anti-refugee, anti-European, and
anti-German themes. Many of the arguments overlapped with right-wing discourse (GPC).

The difference is that the tabloids play on emotions from the very beginning, referring primarily to fear. Both dailies publish emotional texts (and photos) showing the difficult and dangerous situation in Hungary, the "invasions" of migrants from Muslim countries, and riots in Western Europe. The intensity of emotions is significantly greater than in the broadsheet press.

Fakt also focused on the 'mess' in the European Commission and the uncoordinated actions of individual countries. This is the second, popular theme of showing the effects of the migration crisis-the indolence of Europe, quarrels between EU member states, attempts to impose obligatory relocation of migrants on Poland.

In June 2017, both tabloids covered similar topics, including migrant riots, EC policy towards Poland due to quota disputes, and survey results of Polish opinion towards migrants. These are events selected from a broader context, directly referring to the threat by "Others". This type of narrative dominates the message of tabloids.

Analysis of the security context encompassed personal, national and international security threats, while narrowly referring only to negative experiences with migrants. We chose the security context as it combines historical, economic, and political components. The Polish media discourse on migration is mainly dominated by the security aspect. Hence, the study analysed the securitization of migration (Dumitrescu, 2018). 
Further analysis of potential threats appears in certain academic sources (Krzyzanowski, 2018; Georgiou and Zaborowski, 2016), which describe media narratives arguing that uncontrolled migration would create a second-class population deprived of legal residency and, thus, rights to: work, housing, education, attendance of religious services, health care, and social security. Leaving aside cultural concerns, change may be expected in the Polish labour market after the arrival of numerous immigrants (El Ghamari and Bartoszewicz, 2020).

\section{Discussion}

Referring to integrated threat theory (Stephan and Renfro, 2002), Landmann et al. (2019) write "migration elicits two different types of threat: concerns about cultural differences (i.e. symbolic threat) and concerns about specific negative consequences of migration such as financial strain (i.e. realistic threat)." Metaanalytic studies by Cowling et al. qualify this, arguing that symbolic threat has a much greater impact on prejudice against refugees than realistic threat (Cowling et al., 2019, p. 510). Public discourse on refugees is crucial for shaping attitudes, hence the need to map the discourse in detail.

The results of the analysis reveal two disparate discourses, representing two different value systems and appealing to different social groups. Analysis of migration discourse exemplifies the dispute over fundamental values present in many European societies. (Georgiou and Zaborowski, 2016; Eberl et al., 2018; Krzyżanowski, 2018; De Cock et al., 2019)

Gazeta Wyborcza represents the liberal anti-PiS position. Taking a broad perspective, the newspaper makes frequent references to the situation of migrants around the world. An important aspect of $G W$ migration coverage is a far-right activity in Europe. Also, many texts refer to the need for solidarity with refugees, describing internal EU debates on this issue.

GW maintains that shifting Polish attitudes against refugees after 2015 were caused by the prominent anti-immigration policy followed by PiS. GW presents Ukrainian migrants and their impact on the Polish economy in a positive light. It seems that GW follows the moods of Poles, slightly changing the language of description and much more often describing the threats caused by the increasing migration from Africa and the Middle East.

In contrast, the conservative, pro-government Gazeta Polska Codziennie chose to focus on predictions of negative consequences of migration. When discussing foreign affairs, it refers to the fate of migrating Poles, and the transfer to Poland of displaced Ukrainians from the war-stricken Donbas region. There are numerous accounts of anti-refugee protests, visions of European annihilation, and the detrimental effects of refugee activity in the Balkans. Criticism of EC actions and crimes and alleged attacks committed by migrants in Western Europe are constantly recurring themes.

All these elements build an atmosphere of tension and danger. It is clear to the reader that we are dealing with a war of civilizations. In this war, our group is being attacked by malevolent newcomers, even if they have not yet reached Poland.

Given that a large part of the information flow happens online, it is worth paying attention to the filter bubble concept (Vaccari et al., 2016; Dubois and Blank, 2018). Taking this theory into account, the division of the Polish media scene is a major influence on the formation of two camps with opposing attitudes towards migrants. Digital media is particularly influential, because: "people who consume online news tend to hold the most polarized opinions on immigration" (Mertens et al., 2019, p. 150). The division into two hostile camps is visible in all analysed texts. The dominant willingness to attack a political opponent reduces the problem of migration to the instrumental function of a tool.
More importantly, the polarization of the debate on migration may morph into a polarization of political opinions regarding all essential issues. Exposure to a radical discourse reinforces the conviction that the other side employs an equally radical stance. Co ważniejsze, polaryzacja dyskursu o migracjach może przekładać się na polaryzacja poglądów politycznych dotyczących wszystkich istotnych kwestii. Ekspozycja na radykalny dyskurs buduje przekonanie, że druga strona zajmuje równie radykalne stanowisko. 'Exposure to extreme exemplars from the other side makes one thinks that the political opponents are extreme, which in turn may lead people to dislike them' (Yang et al., 2016, p. 13). And the results of these activities clearly favour the dominant political parties to the detriment of smaller groups.

Articles from the opinion-forming press dominate the press discourse. Within this, the specificity of tabloid narratives is noteworthy. Although there are fewer articles devoted to migration, there is no favouring of one political option. There is a variety of opinions and political voices. Overall, as confirmed by studies in other countries, the tabloid view on migration is similar to that of the opinion-forming press (Greussing and Boomgaarden, 2017). The issues raised in the two Polish tabloids on migrants are not so different from those outside Poland. Super Express is dominated by anti-refugee and, importantly, antiGerman discourse, which makes it moderately similar to GPC. The tabloid Fakt- published by Ringer Axel Springer-focuses on criticism of the EU (lack of unanimity on migrants in the EC, riots caused by migrants, and EC actions against Poland). Both, however, refer to the fear of migrants.

The opinion-forming press and the tabloids represent two peaks of journalistic activity: the first appearance, overlapping with other countries (cf. the articles in this volume), the second illustrating the specificity of Polish discourse and, in particular, the ability of the ruling party to impose topics (McCombs, 2004). On the latter point, the crux of the discussion appears not to be the problem of migration per se, rather the dispute between the EC and the Polish government over the imposition of migration quotas.

'Illegal immigrant' was the most popular phrase across all types of press. This highlights consensus on the fundamental assumption that-given the existing legal framework- migration can be legal or illegal. The slogan often used by left-wing movements: 'No one is illegal', appeared infrequently in the media texts analysed.

'Muslim migrants', a phrase that appeared very often, particularly in the right-wing press, points to the emergence of divisions around religion. In the case of Poland, religion is clearly linked to nationality and the common assumption that Polish equals Catholic. Accordingly, it has been argued that: "Religious and political authorities reproduce Polish national ideology to legitimize the territorial divisions between people and the current distribution of power and resources. Polish national ideology developed through mythologizing the past and future of the nation" (Krotofil and Motak, 2018, p. 84)

The more pragmatic opinion recognizes immigration, especially from the East, as an opportunity to rectify Poland's demographic deficit. Polish media see Ukrainian immigrants and Poles sharing a similar culture. In 2016, the Union of Entrepreneurs and Employers published a report on Ukrainian immigration to Poland that identified economic and demographic causes, as well as highlighted the benefits, such as the strong work ethic of immigrants and the cultural proximity of the two nations. The same report assessed outcomes of immigration from Africa and the Middle East for the Polish labour market more pessimistically. Notably, the report attempted to dispel certain fears about Ukrainians among some Poles, including concern that 
Ukrainians harbour Banderist beliefs, hold prejudice against Poles, and would steal jobs (Troszyński, 2018).

Furthermore, for clarity, it is important to distinguish the category of the community as a cultural security actor from all other social groups. The criterion for such a distinction should be its genesis, historical character, clearly defined identity, and political significance. Such a community, nation, or ethnic group may be organized in the form of a state, but this is not necessary. The state and society use different criteria to assess security status (Waever, 1995). While both entities strive for survival, for the state this primarily means the preservation of sovereignty and territorial integrity, whereas society is more concerned with cultural identity. Accordingly, the dualism of the security phenomenon should be acknowledged, with the cultural security of the state seen as distinctly parallel to the cultural security of society. For the above reasons, the social dimension of this phenomenon is of cultural importance. Cultural security can be defined as the ability of a society affected by changing environmental conditions to maintain and develop an independent cultural identity. In other words, these are the conditions in which a given community can consolidate and cultivate the values that determine its essence, and at the same time, freely draw from the experiences and achievements of other nations.

\section{Conclusions}

The media content analysis herein supports the thesis that the polarization of Polish media discourse is valid for discussion. As Głowacki and Kuś state, "we identified media outlets openly taking pro- or anti-governmental (and pro-and anti-Law and Justice) positions" (2019, p. 106) and this reflects how the press discourse on migration is constructed. The role of the Catholic Church in Poland should not be underestimated. Homilies on "compassion and giving can easily be distorted and appropriated to legitimize the privileged position of the in-group, defined as a national-religious entity, and juxtaposed with strangers, represented as 'religious others"' (Krotofil and Motak, 2018, p. 85).

There was no positive migration discourse in the analysed data; this was especially evident after collocation analysis. The tone of the scrutinized texts was verged between moderately negative $(G W)$ and strongly negative (GPC). This phenomenon is confirmed by analyses of other European countries: "There is ample evidence that negative sentiment is growing (...): people in Europe worry that newcomers may not integrate successfully in their host countries and that they may not be able or willing to adopt 'European values', however fluid the interpretation of the concept may be. Europeans are not uniform in their sentiment toward refugees" (Mertens et al., 2019, p. 155).

The results of our study show that the categories "migrant" and "refugee", despite their defined meaning, are used interchangeably in the media discourse.

The media (press) releases discussed here strongly confirm the invocation of the securatization theory. The qualitative analysis showed that the meaning of the recorded speech acts, the transformation of repetitive events into security issues is a frequently used rhetorical ploy. However, the theme of fear and insecurity has much more weight in the right-wing press. It could be argued that this tactic is abused, or rather instrumentally treated by the conservative media. This is supposed to deepen the polarization of society, which preserves the status quo. Additionally, quantitative studies show that "power is derived from the use of appropriate words", as we wrote earlier.

Today's geopolitics-challenged by societal polarization both in Europe and globally- demands greater investigation of how media discourse shapes public opinion on migration, important for a world of widening political division.

\section{Data availability}

The datasets used and analysed during the current study are available from the authors on reasonable request.

Received: 15 July 2021; Accepted: 21 December 2021; Published online: 24 January 2022

\section{Note}

1 A number of occurrences (hits) of an item per million tokens, also called i.p.m. (instances per million). This is used to compare frequencies between corpora of different sizes, https://www.sketchengine.eu/my_keywords/freqmill/

\section{References}

Bączkowska A (2019) A corpus-assisted critical discourse analysis of "migrants" and "migration" in the British Tabloids and Quality Press. In: LewandowskaTomaszczyk B (ed) Contacts and contrasts in cultures and languages. Springer, pp. 163-181

Baker P (2004) Querying keywords: questions of difference, frequency, and sense in keywords analysis. J Engl Linguist 32:346-359. https://doi.org/10.1177/ 0075424204269894

Baker P (2006) Using corpora in discourse analysis. Continuum, London, New York, NY

Baker P, Gabrielatos C, Khosravinik M et al. (2008) A useful methodological synergy? Combining critical discourse analysis and corpus linguistics to examine discourses of refugees and asylum seekers in the UK press. Discourse Soc 19:273-306. https://doi.org/10.1177/0957926508088962

Balzacq T (2005) The three faces of securitization: political agency, audience and context. Eur J Int Relat 11(2):171-201. https://doi.org/10.1177/ 1354066105052960

Balzacq T (2011) A Theory of Securitisation: origins, core assumptions, and variants. In: Balzacq $\mathrm{T}$ (ed) Securitization Theory: how security problems emerge and dissolve. Routledge, Abingdon, pp. 1-30

Bartoszewicz MG (2016) Festung Europa: securitization of migration and radicalization of European Societies. Acta Univ Carol Studia Territ 16:11-37.

Bednarek M (2009) Corpora and discourse: a three-pronged approach to analyzing linguistic data. In: Haugh M et al. (eds) Selected proceedings of the 2008 HCSNet workshop on designing the Australian National Corpus. Cascadilla Proceedings Project, Somerville, MA, pp. 19-24

Bigo D (2002) Security and Immigration: toward a critique of the governmentality of unease. Altern-atives 27(Special Issue):63-92

Bigo D (2000) When two become one: internal and external securitisation in Europe. In: Kelstrup M, Williams MC (eds) International Relations Theory and the politics of European Integration. Power, security and community. Routledge, London, pp. 171-204

Bigo D (2001) Migration and security. In: Guiraudon V, Joppke C (eds) Controlling a new migration world. Routledge, London, pp 121-149

Boćkowski D (2020) Społeczeństwo polskie wobec diaspory czeczeńskiej 1994-2020. Dzieje Najnow 52:349-364

Bourbeau P (2011) The securitization of migration: a study of movement and order. Taylor \& Francis, London, pp. 23-79

Buzan B, de Wilde J, Waever O (1998) Security. A new framework for analysis. Lynne Rienner, Boulder, CO

Carling J (2017) Refugee advocacy and the meaning of 'migrants'. PRIO Policy Brief, p. 2.

CBOS (2016) Stosunek Polakow do przyjmowania uchodzcow [The attitude of the Poles to receive refugees]. https://www.cbos.pl/SPISKOM.POL/2016/ K_012_16.PDF. Accessed 10 Nov 2021

Chadwick A (2013) The hybrid media system: politics and power. Oxford University Press, Oxford, pp. 53-79

Côté A (2016) Agents without agency: assessing the role of the audience in securitization theory. Secur Dialogue 47(6):541-558. https://doi.org/10.1177/ 0967010616672150

Cowling MM, Anderson JR, Ferguson R (2019) Prejudice-relevant correlates of attitudes towards refugees: a meta-analysis. J Refug Stud 32(3):502-24. https://doi.org/10.1093/jrs/fey062

De Cock R, Sundin E, Mistiaen V (2019) The refugee situation as portrayed in news media: In: d'Haenens L, Joris W, Heinderyckx F (eds) Images of immigrants and refugees in Western Europe. Leuven University Press, pp. 39-56

Doty RL (1996) Immigration and national identity: constructing the nation. Rev Int Stud 22(3):235-55

Dubois E, Blank G (2018) The echo chamber is overstated: the moderating effect of political interest and diverse media. Inf Commun Soc 21:729-745. https:// doi.org/10.1080/1369118X.2018.1428656.

Dumitrescu L (2018) The Securitization of East-European migrants. The occurrence of liminal identities in the European Union: realities and media 
representations. In: Balica E, Marinescu V (eds) Migration and crime. Palgrave Macmillan, Cham

Eberl J-M, Meltzer CE, Heidenreich T et al. (2018) The European media discourse on immigration and its effects: a literature review. Ann Int Commun Assoc. https://doi.org/10.1080/23808985.2018.1497452

El Ghamari M, Bartoszewicz MG (2020) (Un)Sustainable development of minors in Libyan Refugee Camps in the context of conflict-induced migration. Sustainability 12(11):4537. https://doi.org/10.3390/su12114537

Eriksson J (1999) Agendas, threats, and politics: securitisation in Sweden. Paper presented at the ECPR Joint Mannheim, March 26-31

Fairclough N (2000) New Labour, New Language? Routledge, London

Friginal E, Hardy JA (eds) (2021) The Routledge handbook of corpus approaches to discourse analysis. Routledge, London, New York

FRAN Quarterly (2015) Q4. Warsaw

FRAN Quarterly (2018) Q2. Warsaw

Gabrielatos C, Baker P (2008) Fleeing, sneaking, flooding: s corpus analysis of discursive constructions of refugees and Asylum Seekers in the UK Press, 1996-2005. J English Linguist 36:5-38. https://doi.org/10.1177/ 0075424207311247

Georgiou M, Zaborowski R (2016) Report: media coverage of the "refugee": a crossEuropean perspective Executive Summary

Głowacki M, Kuś M (2019) Media accountability meets media polarisation. A case study from Poland. In: Eberwein T, Fengler S, Karmasin M (eds) Media accountability in the era of posttruth politics. Routledge, New York, London

Greussing E, Boomgaarden HG (2017) Shifting the refugee narrative? An automated frame analysis of Europe's 2015 refugee crisis. J Ethn Migr Stud 43: https://doi.org/10.1080/1369183X.2017.1282813

Gruszczynski M, Wagner MW (2017) Information flow in the 21st century: the dynamics of agenda-uptake. Mass Commun Soc 20:378-402. https://doi.org/ $10.1080 / 15205436.2016 .1255757$

Hunston S (2002) Corpora in applied linguistics. Cambridge University Press, Cambridge

Huysmans J (2006) The politics of insecurity: fear, migration and asylum in the EU. London: Routledge.

Iyengar S, Hahn KS (2009) Red media, blue media: evidence of ideological selectivity in media use. J Commun 59:19-39. https://doi.org/10.1111/j.14602466.2008.01402.x

Kilgarriff A (2009) Simple maths for keywords. Proc Corpus Linguist Conf Liverpool, UK 20096

Krotofil J, Motak D (2018) Between traditionalism, fundamentalism, and populism: a critical discourse analysis of the media coverage of the migration crisis in Poland. In: Schmiedel U, Smith G (eds) Religion in the European refugee crisis. Palgrave Macmillan, pp. 61-85

Krzyżanowski M (2018) Discursive shifts in ethno-nationalist politics: on politicization and mediatization of the "refugee crisis" in Poland. J Immigr Refug Stud 16:76-96. https://doi.org/10.1080/15562948.2017.1317897

Krzyżanowski M, Forchtner B (2016) Theories and concepts in critical discourse studies: Facing challenges, moving beyond foundations. Discourse Soc 27:253-261. https://doi.org/10.1177/0957926516630900

Landmann H, Gaschler R, Rohmann A (2019) What is threatening about refugees? Identifying different types of threat and their association with emotional responses and attitudes towards refugee migration. Eur J Soc Psychol 49(7):1401-1420. https://doi.org/10.1002/ejsp.2593

Léonard C, Kaunert S (2011) Reconceptualizing the audience in securitization theory. In: Balzacq T (ed) Securitization theory: how security problems emerge and dissolve. PRIO new security studies. Routledge, London, pp. 57-76

Li X (1998) Web page design and graphic use of three US newspapers. J Mass Commun Q 75:353-365

Mautner G (2007) Mining large corpora for social information: the case of elderly. Lang Soc 36:51-72

McCombs M (2004) Setting the agenda. The mass media and public opinion. Polity Press, Cambridge

Mertens S, D'Haenens L, De Cock R (2019) Online news consumption and public sentiment toward refugees: In: d'Haenens L, Joris W, Heinderyckx F (eds) Images of immigrants and refugees in Western Europe. Leuven University Press, pp. $141-158$

Nartey M, Mwinlaaru IN (2019) Towards a decade of synergising corpus linguistics and critical discourse analysis: a meta-analysis. Corpora 14:203-235. https:// doi.org/10.3366/cor.2019.0169

Pierson P (2004) Politics in time: history, institutions, and social analysis. Princetown University Press.

Piper A (2000) Some people have credit cards and others have Giro cheques: "individuals" and "people" as lifelong learners in late modernity. Discourse Soc 11:515-42

Reinemann C (2004) Routine reliance revisited: exploring media importance for German political journalists. J Mass Commun Q 81 https://doi.org/10.1177/ 107769900408100409
Reisigl M, Wodak R (2001) Discourse and discrimination: rhetorics of racism and anti-semitism. Routledge, London

Roe P (2008) Actor, audience(s) and emergency measures: securitization and the UK's decision to invade Iraq. Secur Dialogue 39(6):615-635

Sayad A (1991) L'immigration ou les paradoxes de l'altérité. De Boeck, Bruxelles.

Sayad A (1994) 'L'asile "l'espace Schengen": la définition de l'autre (immigré ouréfugié) comme enjeu de luttes sociales'. In: Caloz-Tschopp M-C, Clevenot A, Tschopp M-P (eds), pp. 193-238

Sinclair J (1991) Corpus, concordance, collocation. Oxford University Press, Oxford

Stephan WG, Renfro C (2002). The role of threats in intergroup relations. In: Mackie DM, Smith ER (eds) From prejudice to inter-group emotions: differentiated reactions to social groups. Psychology Press, New York.

Stritzel H (2007) Towards a Theory of Securitization: Copenhagen and beyond. Eur J Int Relat 13(3):357-383. https://doi.org/10.1177/1354066107080128

Stritzel H (2014) Security in translation: securitization theory and the localization of threat. Palgrave Macmillan, Basingstoke.

Troszyński M (2018) Ukraina i Ukraincy w polskim dyskursie internetowym. Analiza jakościowo-ilościowa tekstów zamieszczanych $\mathrm{w}$ mediach społecznościowych Ukraine and Ukrainians in the Polish internet discourse. Qualitative and quantitative analysis of texts published in social media]. In: Tyma P (ed) Mniejszość ukraińska i migranci z Ukrainy w Polsce. Analiza dyskursu. Związek Ukraińców w Polsce

Troszyński M (2021) History and the media: historical discourse in the Polish media on the 100th anniversary of Poland's independence. In: Stryjek T, Konieczna-Sałamatin J (eds) The politics of memory in Poland and Ukraine: from reconciliation to de-conciliation. Routledge, pp. 169-187

Ugur M (1995) Freedom of movement vs. exclusion: a reinterpretation of the "insider"-"outsider" divide in the European Union. Int Migr Rev 29(4):964-99

UNHCR (2011) Global trends 2011. A year of crises. https://www.unhcr.org/ statistics/country/4fd6f87f9/unhcr-global-trends-2011.html. Accessed 22 Nov 2021

Vaccari C, Valeriani A, Barberá P, Jost JT, Nagler J, Tucker JA (2016) Of echo chambers and Contrarian clubs: exposure to political disagreement among German and Italian users of Twitter. Soc Media Soc 2. https://doi.org/ $10.1177 / 2056305116664221$

Waever O (1995) Securitization and desecuritization. In Lipschutz RD (ed) On security. Columbia University Press, New York, pp. 48-86

Wenzel M, Żerkowska-Balas M (2019) Framing effect of media portrayal of migrants to the European Union: a survey experiment in Poland. East Eur Polit Soc 33:44-65. https://doi.org/10.1177/0888325418777058

Wodak R, van Dijk TA (eds) (2000) Racism at the top. Parliamentary discourses on ethnic issues in six European States. Drava-Verlag, Klagenfurt

Yang JH, Rojas H, Wojcieszak M et al. (2016) Why are "others" so polarized? Perceived political polarization and media use in 10 countries. J Comput Commun 21:349-367. https://doi.org/10.1111/jcc4.12166

ZUS (2020) Rekordowa liczba ubezpieczonych cudzoziemców [A record number of insured foreigners] https://www.zus.pl/o-zus/aktualnosci/-/publisher/ aktualnosc/1/rekordowa-liczba-ubezpieczonychcudzoziemcow/3996120. Accessed 20 Nov 2021

\section{Acknowledgements}

We thank Anthony Goltz BA (Oxon) for the very insightful proofreading. The research and this publication are the result of the project "Migrants. Analysis of media discourse on migrants in Poland, the United Kingdom, Ukraine, Albania and the Czech Republic (MAD)" financed by the Polish National Agency for Academic Exchange as part of the 'International Academic Partnerships' under decision no. PPI/APM/2018/1/00019/DEC/1

\section{Competing interests}

The authors declare no competing interests.

\section{Ethics Approval and Consent to Participate}

This article does not contain any studies with human participants performed by any of the authors. This article does not contain any studies with human participants performed by any of the authors.

\section{Additional information}

Correspondence and requests for materials should be addressed to Marek Troszyński.

Reprints and permission information is available at http://www.nature.com/reprints

Publisher's note Springer Nature remains neutral with regard to jurisdictional claims in published maps and institutional affiliations. 
(c) (i) Open Access This article is licensed under a Creative Commons Attribution 4.0 International License, which permits use, sharing, adaptation, distribution and reproduction in any medium or format, as long as you give appropriate credit to the original author(s) and the source, provide a link to the Creative Commons license, and indicate if changes were made. The images or other third party material in this article are included in the article's Creative Commons license, unless indicated otherwise in a credit line to the material. If material is not included in the article's Creative Commons license and your intended use is not permitted by statutory regulation or exceeds the permitted use, you will need to obtain permission directly from the copyright holder. To view a copy of this license, visit http://creativecommons.org/ licenses/by/4.0/.

(C) The Author(s) 2022 